\title{
PROFIL USAHA BUDIDAYA IKAN LELE DI KABUPATEN BOGOR
}

\author{
Tikkyrino Kurniawan dan Riesti Triyanti \\ Balai Besar Penelitian Sosial Ekonomi Kelautan dan Perikanan \\ JI. KS. Tubun Petamburan VI Jakarta 10260 \\ Telp. (021) 53650162, Fax. (021)53650159 \\ Diterima 19 Oktober 2011 - Disetujui 29 November 2011
}

\begin{abstract}
ABSTRAK
Penetapan kawasan Minapolitan untuk meningkatkan produksi perikanan menjadi 353\% pada 2014 memerlukan kesiapan infrastruktur dan kebijakan dilapangan. Kabupaten Bogor telah ditetapkan sebagai kawasan Minapolitan budidaya air tawar dengan lele sebagai komoditas utama. Namun Pengembang biakan lele membutuhkan perbandingan satu banding satu, sehingga untuk menghasilkan berat lele tertentu menbutuhkan pakan yang cukup banyak. Untuk itu perlu adanya evaluasi setiap tahunnya untuk melihat kesiapan program Minapolitan tersebut khususnya Minapolitan Budidaya. Sedangkan pemilihan responden bersifat random purposive sampling. Analisis deskriptif yang dipakai untuk menjelaskan keadaan dan gejala yang terjadi. Penelitian berlangsung di Kabupaten Bogor. Dengan tingginya harga pangan dan rendahnya harga jual, maka banyak pembudidaya di kabupaten bogor yang gulung tikar dan tidak sanggup untuk melanjutkan budidaya lele tersebut. Operasional untuk produksi lele tersebut tidak menutupi karena luas lahan yang tidak begitu besar dan jumlah lahanya yang sedikit menyebabkan biaya pakan cukup tinggi karena tidak di beli dalam jumlah banyak. Pembesaran yang bertahan adalah milih perseorangan dan mempunyai jumlah kolam yang lebih dari 5 unit. Beberapa hal yang bisa dilakukan oleh pemerintah adalah perlu diadakannya pelatihan kembali cara pembudidaya yang baik dan benar, memperkuat kelembagaan pembudiaya, membentuk lembaga pemasaran yang bisa menyetabilkan harga dan meningkatkan harga jual ke pasaran, serta menyetabilkan harga bahan pakan agar dapat meningkatkan daya saing penjualan lele.
\end{abstract}

Kata kunci: Minapolitan, Bogor, Lele, Perikanan

\section{PENDAHULUAN}

Penetapan kawasan Minapolitan merupakan upaya pemerintah untuk meningkatkan produksi perikanan sebesar 353\% pada tahun 2014 telah dilakukan dengan terbitnya Keputusan Menteri Kelautan dan Perikanan No 32 tahun 2010 (Kementerian Kelautan dan Perikanan, 2010). Bogor adalah salah satu kabupaten yang sudah ditetapkan dalam keputusan menteri tersebut. Selain itu Dirjen Budidaya juga sudah menetapkan Bogor sebagai kawasan minapolitan budidaya air tawar dengan komoditas utama ikan lele. Penetapan kawasan minapolitan dengan komoditas utama ikan lele dimaksudkan untuk meningkatkan produksi ikan lele mulai dari pembenihan, pembesaran hingga pengolahan produk berbahan baku lele.

Penetapan kawasan penghasil lele ini belum tentu diiringi dengan kesiapan dilokasi. Sebagai contoh banyak lahan-lahan budidaya lele yang terlantar dan tidak terurus. Hasil observasi menunjukkan bahwa banyak pembudidaya lele yang sudah tidak melakukan budidaya lagi. Mereka tidak mempunyai modal yang kuat untuk melakukan budidaya ikan lele. Pengembangbiakan ikan lele membutuhkan perbandingan jantan betina satu banding satu, bahkan lebih, sehingga untuk menghasilkan berat lele tertentu membutuhkan pakan ikan yang cukup banyak.

Selain pembenihan dan pembesaran, seharusnya di kawasan minapolitan itu juga memiliki pengolahan produk yang menggunakan bahan baku yang ada. Namun permasalahan yang ada adalah belum berkembangnya pengolahan produk berbahan baku lele di Kecamatan
Ciseeng. Hal ini diperparah dengan bangkrutnya sebagian pembesaran lele tingkat usaha kecil, sehingga bahan baku untuk pengolahan tidak tersedia. Tulisan ini mengemukakan kesiapan program Minapolitan berbasis kegiatan budidaya lele di Kabupaten Bogor. Evaluasi tidak hanya melihat kesiapan dari hasil produksinya saja, namun mencakup aspek sosial ekonomi. Produksi tidak hanya memenuhi kuantitas produksi lelenya saja, akan tetapi kualitas produksinya serta biaya produksinya sendiri. Jika evaluasi tidak dilakukan, dikhawatirkan pada 2014 KKP tidak akan siap untuk menjadi produsen ikan terbesar (Ruslan, 2011).

Data dan informasi tentang budidaya lele ini di dapatkan dari informan kunci yaitu pembudidaya yang sudah lama melakukan budidaya ikan lele dan pembudidaya ikan lele lainnya. Pembudidaya ini adalah pembudidaya level menengah, yang memiliki lebih dari 10 kolam untuk budidaya, sehingga memungkinkan mereka untuk memanen hampir setiap bulannya. Analisis data yang digunakan secara deskriptif untuk menjelaskan keadaan dan gejala yang terjadi dari pengamatan di daerah penelitian.

\section{SKALA USAHA PEMBUDIDAYAAN IKAN}

Skala usaha di bidang perikanan budidaya air tawar dibedakan atas empat (4) skala usaha, yaitu skala usaha mikro, skala usaha kecil, skala usaha menengah dan skala usaha besar yang dibakukan dalam Peraturan Menteri Kelautan dan Perikanan No. PER.05/MEN/2009 dengan ciri aset, omset, tenaga kerja, teknologi dan status hukum pada Tabel 1. 
Tabel 1. Skala Usaha di Bidang Perikanan Budidaya Air Tawar Berdasarkan PERMENKP NO. PER.05/MEN/2009

\begin{tabular}{|c|c|c|c|c|c|}
\hline No & Parameter & Skala Mikro & Skala Kecil & Skala Menengah & Skala Besar \\
\hline \multirow[t]{3}{*}{1} & Aset: & & & & \\
\hline & - Modal & $<50$ Juta & $50-200$ juta & $200-300$ juta & > 300 juta \\
\hline & - Volume/Luas Unit Usaha & $<1.000 \mathrm{~m}^{2}$ & $1.000-5.000 \mathrm{~m}^{2}$ & $5.000-10.000 \mathrm{~m}^{2}$ & $>10.000 \mathrm{~m}^{2}$ \\
\hline \multirow[t]{2}{*}{2} & Omset & & & & \\
\hline & - Hasil penjualan/ tahun & $<60$ juta & $60-250$ juta & $250-500$ juta & $>500$ juta \\
\hline 3 & Jumlah Tenaga Kerja & $<2$ orang & $2-5$ orang & $5-10$ orang & $>10$ orang \\
\hline 4 & Penerapan Teknologi & Non Intensif & Intensif & Intensif & Intensif \\
\hline 5 & Status Hukum dan Perijinan & TDUP & SIUP & SIUP & SIUP \\
\hline
\end{tabular}

Sumber: KKP, 2009

Berdasarkan Tabel 1 terlihat bahwa sebagian besar pembudidaya di Kecamatan Ciseeng termasuk ke dalam kategori skala usaha micro karena mereka hanya bekerja sendiri walau terkadang di bantu oleh anggota keluarga/temannya, luas lahan yang tidak begitu besar dan tanpa perijinan. Beberapa pembudidaya ikan lele milik perorangan yang lainnya memiliki skala usaha menengah.

\section{TEKNIK BUDIDAYA DAN PEMASARAN IKAN LELE}

Cara budidaya pembesaran ikan lele di Kabupaten Bogor adalah sebagai berikut: bibit ikan lele yang sudah berusia 1 minggu mulai di pindahkan ke dalam kolam ikan lele. Dari usia seminggu hingga 3-4 ikan lele tidak diberi pakan dan dibiarkan hidup begitu saja. Setelah 3-4 minggu hingga 1 bulan maka bibit ikan lele diberi pakan yang paling halus. Pada umur satu (1) hinggu dua (2) bulan diberi pakan ukuran 1. Umur lele 2 bulan hingga panen diberi pakan ukuran besar yaitu ukuran 4 .

Berdasarkan data BPS, tingkat konsumsi ikan, termasuk lele di Indonesia terus meningkat (Anonim 2011). Konsumsi ikan lele terus meningkat dari tahun 2004 hingga 2007. Pada tahun 2004 konsumsi lele terhitung 22,58 kg per kapita per tahun, sedangkan tahun 2007 konsumsinya mencapai 29,98 kg perkapita per tahun. Produksi ikan lele berkontribusi sebesar $10 \%$ dari produksi perikanan budidaya nasional (Anonim 2011, Ajib 2009). Tingkat pertumbuhan produksi ikan lele itu sendiri mencapai $17-18 \%$ pertahun (Anonim 2011). Berdasarkan data diatas, tingkat konsumsi ikan lele cukup tinggi.

Ikan lele cukup di gemari walau tidak berfungsi sebagai makanan/lauk yang paling sering dimakan. Tujuan pemasaran ikan lele dari Kabupaten Bogor adalah ke Parung, Bogor dan Jakarta untuk digunakan sebagai usaha pecel lele. Berdasarkan Ajib (2009) tingkat serapan pasar terhadap ikan lele tergolong cukup tinggi, baik pasar dalam negeri maupun luar negeri. Prospek penjualan ikan lele termasuk cukup tinggi dan cukup menguntungkan.

\section{STRUKTUR BIAYA PRODUKSI DAN KEUNTUNGAN USAHA}

Budidaya lele yang dibilang mudah tampaknya tidak terlalu mudah seperti kelihatanya. Anggapan orang yang hanya meletakkan lele di kolam akan besar dengan sendirinya tidak sepenuhnya benar. Lele sebagai komoditas perikanan juga memerlukan perawatan dan pakan yang benar untuk mencapai besaran tertentu. Hal ini di tunjang dengan data dan tulisan oleh Mahyuddin (2009) yang menunjukkan bahwa FCR (Feed Conversion Ratio) lele adalah 1, yang berarti untuk $1 \mathrm{~kg}$ daging lele dibutuhkan $1 \mathrm{~kg}$ pakan. Sehingga pembesaran lele tidaklah semudah yang dibayangkan karena membutuhkan banyak pakan dan bergantung kepada harga pakan yang terus meningkat.

Tabel 2 menyajikan perhitungan biaya untuk usaha pembudidaya ikan lele yang diperoleh melalui wawancara. Biaya tetap yang selalu dikeluarkan adalah pajak, karena sebagain besar memiliki lahannya masingmasing. Biaya operasional yang harus dikeluarkan adalah harga benih, pakan pemula, pakan lanjutan, vitamin, obat-obatan, pupuk, kapur, tenaga kerja, listrik, biaya renovasi kolam, dan biaya panen. Pendapatan yang berasal dari penjualan ikan lele yang diproduksi oleh pembudidaya tersebut dikemukakan pula pada Tabel 2 .

Pembudidaya tingkat usaha menengah dengan lebih dari satu kolam dapat membesarkan kurang lebih 40.000 ekor bibit lele. Dengan jumlah itu, rasio yang mati adalah $10 \%$ serta pada saat penjualan pembudidaya mentargetkan ukuran lele 8-10 ekor per kilogram, maka pembudidaya bisa mendapatkan $3900 \mathrm{~kg}$ untuk di jual ke pedagang pengumpul. Asumsi ini harus ditunjang pakan sebesar 130 sak x 30 kg untuk mendapatkan $3900 \mathrm{Kg}$ ikan. Dari hasil perhitungan pada Tabel 1, pedagang mendapatkan keuntungan yang cukup besar pada jangka waktu 2 bulanan. 
Tabel 2. Struktur Biaya dan Keuntungan Usaha Budidaya Ikan Lele Tingkat Usaha Menengah

\begin{tabular}{lccrr}
\hline \multicolumn{1}{c}{ Item } & Harga per Satuan & Satuan & Ukuran & Total \\
\hline Biaya Tetap & & & & \\
Pajak & 29.167 & Bulan & 2 & 29.167 \\
Biaya Operasional & & & & \\
Benih & 150 & Ekor & 40.000 & 6.000 .000 \\
Pakan Pemula & 150.000 & Sak & 1 & 150.000 \\
Pakan Lanjutan & 200.000 & Sak & 130 & 26.000 .000 \\
Vitamin & 30.000 & Botol & 1 & 30.000 \\
Obat-obatan & 150.000 & Sak & 1 & 150.000 \\
Kapur & 10.000 & Karung & 2 & 20.000 \\
Tenaga Kerja & 1.200 .000 & Sak & 5 & 6.000 .000 \\
Listrik & 180.000 & Org/hr & 2 & 180.000 \\
Renovasi Kolam & 35.000 & Org/hr & 2 & 70.000 \\
Panen & 40.000 & Karung & 5 & 200.000 \\
Total Biaya & & & & $\mathbf{3 8 . 6 2 9 . 1 6 7}$ \\
Pendapatan & 12.000 & Kg & 3.600 & $\mathbf{4 3 . 2 0 0 . 0 0 0}$ \\
Keuntungan & & & $\mathbf{3 . 2 1 9}$ \\
$\quad$ Keuntungan perbulan & & & & $\mathbf{1 0 . 7 3 0}$ \\
B/C Rasio & & & & 2.285 .417 \\
BEP produksi & & & & $\mathbf{2}$ \\
\hline BEP Harga & & & & \\
\hline
\end{tabular}

Sumber: Data Pimer diolah, 2010

Tenaga kerja yang digunakan minimal berjumlah lima (5) orang dan bisa lebih dari 10 orang. Untuk perhitungan penjaganya 5 orang, penjaganya tinggal di lokasi pembudidayaan sebanyak 5 orang pekerja. Mereka diberikan gaji sebesar Rp. 600.000,- per bulannya dan untuk memanen sebesar Rp. 40.000,- per orang perhari, serta upah renovasi jika ada kerusakan sebesar Rp. 35.000,-. Perhitungan ini hanya untuk sekali tebar dan sekali panen. Padahal pengusaha menengah ini mempunyai lebih dari 5 kolam, ada yang 20 dan ada yang lebih dari itu. Mereka bisa memanen lebih dari sekali dalam satu bulannya. Hanya gaji perbulan saja yang tidak berubah jika jumlah kolam semakin banyak, sehingga keuntungan akan semakin banyak jika jumlah kolam semakin banyak.

Pembudidaya tingkat usaha kecil dan mikro yang hanya mempunyai 1 atau 2 kolam tidak merasakan manfaat seperti pembudidaya tingkat usaha menengah. Pembudidaya tingkat usaha kecil dan mikro tidak dapat ditemui pada saat survey karena sudah tidak berusaha lagi/mengalami kerugian. Gambaran usaha pembudidaya tingkat usaha mikro disajikan pada Tabel 3. Berdasarkan informasi dari responden yang pernah mencoba budidaya ikan lele, selaku pembudidaya tingkat usaha mikro mereka hanya mampu membeli 20.000 ekor benih ikan lele dengan biaya operasional seperti vitamin, obat-obatan, kapur, tenaga kerja dan biaya renovasi serta panen yang tidak jauh berbeda dengan pembudiaya tingkat usaha menengah. Jika dihitung usahanya, pembudidaya tingkat usaha kecil mengalami kerugian karena harga pakan yang mahal untuk jumlah ikan yang tidak banyak, sehingga biaya per-ekor ikan atau per-kilogramnya jadi lebih mahal. Hal lain yang membedakan adalah pembudidaya pada tingkat usaha menengah yang membutuhkan pakan yang banyak akan mencari distributor atau produser pakannya langsung sehingga bisa lebih leluasa bernegosiasi harga atau meminta diskon untuk pembelian pakan dalam jumlah tertentu.

Pembudidaya tingkat usaha menengah juga lebih banyak memproduksi lele yang berarti lebih mempunyai stok jika dibandingkan dengan pembudidaya tingkat usaha kecil. Hal ini disebabkan karena pembudidaya tingkat kecil mengalami kematian lele sekitar 50\% hingga total sehingga hasil produksinya tidak dapat dikontrol. Keuntungan lain yang dimiliki oleh pembudidaya tingkat usaha menengah adalah bisa mengatur kapan panen, sehingga keberlanjutan produksi lebih terjamin. Dengan adanya hal ini maka pembudidaya tingkat usaha menengah bisa lebih menstabilkan harga pada harga maksimum harga jual produsen yaitu Rp. 12.000,-Pembudidaya yang kecil cenderung melakukan sekali panen saja. Kelemahan yang sering dihadapi adalah harga yang turun drastis sampai pada harga terendah jika kelebihan/banjir pasokan. 
Tabel 3. Struktur Biaya dan Keuntungan Usaha Budidaya Ikan Lele Tingkat Usaha Micro (Prediksi)

\begin{tabular}{|c|c|c|c|c|}
\hline Item & Harga perSatuan & Satuan & Ukuran & Total \\
\hline \multicolumn{5}{|l|}{ Biaya Tetap } \\
\hline Pajak & 4.167 & Dulan & 2 & 4.167 \\
\hline \multicolumn{5}{|l|}{ Biaya Operasional } \\
\hline Benih & 150 & Ekor & 20.000 & 3.000 .000 \\
\hline Pakan Pemula & 150.000 & \multirow{2}{*}{$\begin{array}{l}\text { Sak } \\
\text { Sak }\end{array}$} & 1 & 150.000 \\
\hline Pakan Lanjutan & 200.000 & & 30 & 6.000 .000 \\
\hline Vitamin & 30.000 & \multirow{2}{*}{ Botol } & \multirow{2}{*}{1} & 30.000 \\
\hline Obat-obatan & 150.000 & & & 150.000 \\
\hline Kapur & 10.000 & $\begin{array}{c}\text { Sak } \\
\text { Karung }\end{array}$ & $\frac{1}{1}$ & 10.000 \\
\hline Tenaga Kerja & 20.000 & Sak & 1 & 40.000 \\
\hline Renovasi Kolam & 35.000 & Org/hr & 2 & 70.000 \\
\hline Panen & 40.000 & $\mathrm{Org} / \mathrm{hr}$ & 4 & 160.000 \\
\hline Total Biaya & & & & 9.610 .000 \\
\hline Pendapatan & 10.000 & $\mathrm{Kg}$ & 1000 & 10.000 .000 \\
\hline Keuntungan & & & & 390.000 \\
\hline Keuntungan perbulan & & & & 195.000 \\
\hline B/C Rasio & & & & 1,04 \\
\hline BEP produksi & & & & 961 \\
\hline BEP Harga & & & & 9.610 \\
\hline
\end{tabular}

Sumber: Data Pimer diolah, 2010

Selain harga pakan yang tinggi, pemasaran ikan lele juga menjadi kendala. Stok ikan yang terbanyak adalah pada pembudidaya tingkat usaha menengah karena produksinya lebih banyak. Pengumpul akan berusaha mencari produsen ikan yang lebih menjanjikan, selain untuk memperkecil biaya transportasi, juga mengurangi waktu untuk mencari siapa produsen yang siap dibeli sehingga pembudidaya tingkat menengah akan lebih sering dicari oleh pembeli. Akan tetapi tidak tertutup kemungkinan pembudidaya pada tingkat usaha kecil juga memiliki nomer telpon pengumpul yang menjadi langganan mereka tapi harga sangat ditentukan oleh pengumpulnya.

\section{KEUNTUNGAN USAHAPADA BERBAGAITINGKATHARGA JUAL IKAN}

Pembudidaya akan mengenakan harga jual yang berlaku dengan memperhitungkan komponen biaya operasional termasuk bibit, pakan dan tenaga kerja; waktu pembesaran; biaya peralatan; serta keuntungan. Dengan penjumlahan biaya-biaya tersebut, maka pembudidaya mengenakan harga produksi. Harga produksi ini tidak begitu mahal. Harga pembudidaya dapat turun jika pada satu lokasi terdapat banjir produksi lele, sehingga harganya bisa turun drastis dan terkadang merugikan pembudidaya karena tidak menutupi biaya operasional mereka.
Penjual akan mengenakan harga jual yang berlaku dengan komponen biaya operasional termasuk harga yang dibeli dari pembudidaya, biaya transportasi, upah-upah yang ada; serta keuntungan bagi si penjual. Keuntungan si penjual ini biasanya lebih besar dari pada keuntungan si pembudidaya. Harga pedagang ikan cendertung lebih stabil karena area distribusi mereka cenderung lebih besar daripada pembudidaya. Keuntungan yang diperoleh pedagang bisa lebih banyak karena pedagang ikan lebih mengerti pasar daripada pembudidaya. Pembeli membeli ikan tergantung pada selera, kondisi keuangan dan kemudahan mereka memperoleh jenis ikan tersebut. Pada situasi seperti ini maka hukum ekonomi berlaku, pembeli dan penjual akan menegosiasikan harga sehingga mencapai titik sepakat.

Pembudidaya tingkat menengah memiliki BEP Produksinya 3.219 (< 3.900), dengan BEP harga 10.730 (< 12.000), dan R/C Rationya 1.12 . Dari data tersebut dapat dilihat bahwa usaha budidaya tingkat menengah cukup menguntungkan. Pembudidaya tingkat kecil memiliki BEP Produksinya 929 (< 1.000), dengan BEP harga 9.610 (< 10.000), dan R/C Rationya 1.04. Dari data tersebut dapat dilihat bahwa usaha budidaya tingkat kecil tidak begitu menguntungkan karena perbedaanya sangat tipis sekali. Jika diteruskan dan terjadi hal-hal yang 
tidak diinginkan, maka pembudidaya tingkat kecil ini mengalami kerugian yang cukup besar dan akan sulit memulai usaha barunya lagi.

Dengan demikian, terlihat bahwa pembudidaya lele tingkat usaha kecil lebih banyak merugi jika dibandingkan pembudidaya lele tingkat usaha menengah. Pada saat ini di Kecamatan Ciseeng terlihat banyak sekali pembudidaya lele yang sudah tidak berproduksi kecuali pembudidaya tingkat usaha menengah dan pembudidaya yang melakukan pembenihan lele untuk dijual kembali kepada pembudidaya tingkat usaha menengah diluar kecamatan.

Tingkat harga yang cukup menguntungkan untuk pembudidaya mendapatkan harga yang dapat meneruskan usaha dan memenuhi kebutuhan mereka adalah pada kisaran diatas Rp. 11.000 (Tabel 4). benih, pakan beserta harganya. Jika penyediaan sarana pendukung produksi perikanan (saprokan) tidak ada atau kurang maka biaya produksi juga akan meningkat jauh. Hal ini berdampak pada pengurangan keuntungan pembudidaya. Untuk itu perlu dibentuk distributor atau lembaga penyedia sarana pendukung produksi perikanan yang dapat mebantu menjual barang-barang kebutuhan pembudidaya dengan harga yang relatif murah. Sebagai contohnya dengan membuat koperasi penyedia alat-alat perikanan.

Selain koperasi, kelembagaan yang sebaiknya ada adalah kelompok pembudidaya. Keuntungan adanya kelompok pembudidaya ini adalah mempermudah penyuluh lapangan mengadakan penyuluhan sehingga para penyuluh bisa bertukar pikiran dengan pembudidaya untuk agar pembudidaya bisa melakukan

Tabel 4. Gambaran Keuntungan Usaha Pada Berbagai Tingkat Harga ikan lele.

\begin{tabular}{ccccc}
\hline Total Biaya & Harga per Kilo & Harga per 3.600 Kg & Keuntungan & Keuntungan perbulan \\
\hline 38.629 .167 & $\mathbf{1 5 . 0 0 0}$ & 54.000 .000 & 15.370 .833 & $\mathbf{7 . 6 8 5 . 4 1 7}$ \\
38.629 .167 & $\mathbf{1 4 . 0 0 0}$ & 50.400 .000 & 11.770 .833 & $\mathbf{5 . 8 8 5 . 4 1 7}$ \\
38.629 .167 & 13.000 & 46.800 .000 & 8.170 .833 & $\mathbf{4 . 0 8 5 . 4 1 7}$ \\
38.629 .167 & 12.000 & 43.200 .000 & 4.570 .833 & $\mathbf{2 . 2 8 5 . 4 1 7}$ \\
38.629 .167 & $\mathbf{1 1 . 0 0 0}$ & 39.600 .000 & 970.833 & $\mathbf{4 8 5 . 4 1 7}$ \\
38.629 .167 & $\mathbf{1 0 . 0 0 0}$ & 36.000 .000 & $(2.629 .167)$ & $\mathbf{( 1 . 3 1 4 . 5 8 4 )}$ \\
38.629 .167 & $\mathbf{9 . 0 0 0}$ & 32.400 .000 & $(6.229 .167)$ & $\mathbf{( 3 . 1 1 4 . 5 8 4 )}$ \\
38.629 .167 & $\mathbf{8 . 0 0 0}$ & 28.800 .000 & $(9.829 .167)$ & $\mathbf{( 4 . 9 1 4 . 5 8 4 )}$ \\
\hline
\end{tabular}

Sumber: Hasil Analisa, 2010

Tabel 4 memaparkan gambaran keuntungan pada tingkat harga ikan yang berbeda dengan rata-rata produksi sekitar 3.600 kilogram setiap dua bulannya.

\section{PERMASALAHAN DAN PROSPEK PENGEMBANGAN BUDIDAYA IKAN LELE}

Pengembangan kawasan minapolitan tidak hanya dengan peningkatan produksinya saja, akan tetapi harus juga melihat apa saja yang mengganggu produksi sektor perikanan tersebut. Seperti contohnya penyediaan cara budidaya yang baik dan benar (CBIB). Dengan CBIB ini, pembudidaya dapat melakukan budidaya yang baik dan benar sehingga jumlah kuantitas dan kualitas produksi akan memenuhi persyaratan.

Tenaga kerja juga merupakan salah satu hal yang harus diperhatikan karena merupakan salah satu faktor pendukung produksi. Tenaga kerja untuk pembudidaya tingkat kecil di Kabupaten Bogor umumnya mengunakan tenaga kerja yang berasal dari keluarga dan tetangga pemilik lahan sendiri yang merupakan penduduk lokal.

Tabel 5. Perbedaan Pembudidaya Menengah dan Pembudidaya Kecil

\begin{tabular}{ll}
\hline \multicolumn{1}{c}{ Pembudidaya Tingkat Menengah } & \multicolumn{1}{c}{ Pembudidaya Tingkat Kecil dan Mikro } \\
\hline Jumlah bibit lebih banyak (40.000) & Jumlah bibit lebih sedikit (20.000) \\
Jumlah pakan dibutuhkan lebih banyak & Jumlah pakan dibutuhkan lebih sedikit \\
Harga pakan yang dibeli jatuhnya lebih murah & Harga pakan yang dibeli jatuhnya lebih mahal \\
Biaya operasional per Kg ikan lebih murah & Biaya operasional per Kg ikan lebih mahal \\
Waktu panen bisa diatur & Waktu panen tidak bisa diatur \\
Harga jual lebih stabil & Harga jual mengikuti harga pasar saat itu \\
Lebih sering didatangi pembeli & Lebih jarang didatangi pembeli \\
\hline
\end{tabular}

Sumber: Hasil Analisa, 2010 
Dengan penggunaan tenaga yang berasal dari keluarga sendiri, maka penggajian atau pembayaran upah tenaga kerjanya tidak ada. Dengan tidak adanya pembayaran upah tenaga kerja, maka sering tidak dihitung sebagai biaya produksi sehingga komponen ini tidak menjadi bagian biaya jual.

Pembudidaya tingkat menengah menggunakan penduduk lokal yang dipercaya oleh pemilik lahan yang dimana sebagian besar pekerjanya adalah keluarganya sendiri. Selain dari perhitungan tersebut, pembudidaya tingkat menengah juga mengadakan pengolahan air yang akan masuk ke dalam kolam untuk budidaya. Pengolahan ini menggunakan sebuah kolam kosong sebelum masuk ke dalam kolam budidaya, sehingga air yang masuk kedalam kolam sudah bagus atau aman untuk digunakan untuk membudidayakan ikan lele.

Melihat kondisi diatas diketahui bahwa pembudidaya tingkat kecil dan mikro mempunyai tingkat kerentanan terhadap kegagalan yang cukup tinggi dan yang dapat bertahan jika terjadinya kegagalan adalah pembudidaya tingkat menengah hingga pembudidaya besar. Cara mengantisipasinya dapat dibentuk koperasi atau pengumpul yang mempunyai harga dasar yang cukup tinggi (Rp. 12.000) sehingga tingkat kesejahteraan pembudidaya dapat dipertahankan. Selain itu pula harus dapat mengkoordinir harga bahan pakan agar harga produksi dapat di kontrol.

\section{KESIMPULAN DAN SARAN}

Penetapan Kabupaten Bogor sebagai kawasan minapolitan budidaya dengan komoditas lele harus senantiasa dikontrol atau dikendalikan untuk menyukseskan program minapolitan yang sudah dicanangkan. Dengan tingginya harga pangan dan rendahnya harga jual, maka banyak pembudidaya tingkat usaha kecil di Kabupaten Bogor yang gulung tikar dan tidak sanggup untuk melanjutkan budidaya lele tersebut. Operasional untuk produksi lele tersebut tidak menutupi karena luas lahan yang tidak begitu besar dan jumlah lahanya yang sedikit menyebabkan biaya pakan cukup tinggi karena tidak dibeli dalam jumlah banyak. Pembesaran yang bertahan adalah milih perseorangan dan mempunyai jumlah kolam yang lebih dari 5 unit.
Beberapa hal yang bisa dilakukan oleh pemerintah adalah perlu diadakannya pelatihan kembali cara pembudidaya yang baik dan benar, memperkuat kelembagaan pembudiaya, membentuk lembaga pemasaran yang bisa menstabilkan harga dan meningkatkan harga jual ke pasaran, serta menstabilkan harga bahan pakan agar dapat meningkatkan daya saing penjualan lele. Hal ini dapat dilakukan dengan membentuk koperasi yang dapat menyediakan bahan pakan, serta membeli hasil produksi pembudidaya.

\section{DAFTAR PUSTAKA}

Ahmad, T. et. al. 2007. Budidaya Bandeng Secara Intensif. Penebar Swadaya. Depok. hal 79-89.

Ajib, K. 2009. Tingkat Konsumsi Ikan Naik. Info Makan Ikan. http://aa-ikan.blogspot.com/ 2009/09/tingkat-konsumsi-ikan-naik.html. diakses tanggal 23 Juli 2011.

Anonimous. 2011. Peluang Usaha \& Prospek Pasar Ikan Lele. http://www.ikanlele.net/peluang-usahaprospek-pasar-lele-p-62.html. diakses tanggal 23 Juli 2011.

2009. Peraturan Menteri Kelautan dan Perikanan No. PER.05/MEN/2009 Tentang Skala Usaha diBidang Pembudidayaan Ikan. Kementerian Kelautan dan Perikanan. Jakarta.

. 2010. Keputusan Menteri Kelautan dan Perikanan. No. 32 Tentang Pentapan Lokasi Minapolitan. Kementerian Kelautan dan Perikanan. Jakarta.

Mahyuddin, K. 2009. Panduan Lengkap Agribisnis Lele. Penebar Swadaya. Depok. hal. 30-33, 95, 152160.

Martoyo, J.; A. Nugroho dan T. Winanto. 2006. Budidaya Tripang. Penebar Swadaya. Depok. hal. 58-62.

Ruslan. 2011. Target Peningkatan Perikanan 353 Persen Terancam gagal. (http://www.antaranews. com/berita/1271174784/target-peningkatanperikanan-353-persen-terancam-gagal. diakses tanggal 25 Januari 2011).

Widodo, H. et. al. 2008. Udang Vannamei. Penebar Swadaya. Depok. hal. 70-73. 